PRETHODNO PRIOPĆENJE

UDK: 338.5:621.39

Izv. prof. dr. sc. Sunčana Piri Rajh *

Lidija Lijović, univ. bacc. oec. ${ }^{* *}$

\title{
PERCEPCIJA ODNOSA CIJENE I KVALITETE I CJENOVNA OSJETLJIVOST POTROŠAČA U KUPNJI ELEKTRONIČKIH PROIZVODA
}

\author{
PRICE-QUALITY RELATIONSHIP PERCEPTION \\ AND CONSUMERS' PRICE SENSITIVITY IN THE PURCHASE \\ OF ELECTRONIC PRODUCTS
}

\begin{abstract}
SAŽETAK: Tijekom procesa odlučivanja o kupnji, cijenu proizvoda potrošači mogu dvojako percipirati: kao novčani trošak (cjenovno osjetljiviji potrošači) i kao informaciju o kvaliteti (cjenovno manje osjetljivi potrošači). Cjenovna osjetljivost potrošača, kao i njihova percepcija odnosa cijene i kvalitete, mogu varirati i ovisno o kategoriji proizvoda. Stoga je osnovni cilj rada bio istražiti u kojoj se mjeri potrošači oslanjaju na cijenu kao pokazatelja kvalitete, a koliko su cjenovno osjetljivi u kupnji odabranih kategorija elektroničkih proizvoda (pametnih telefona, prijenosnih računala i televizora). Istraživanje je provedeno metodom online ankete, na prigodnome uzorku od 123 ispitanika koji koriste sve tri kategorije promatranih elektroničkih proizvoda. Rezultati istraživanja su pokazali da postoje dvije skupine proizvoda koje se razlikuju s obzirom na odnos dvije analizirane varijable (odnos cijene i kvalitete te cjenovne osjetljivosti potrošača). Provedeno istraživanje upućuje na važnost razumijevanja dvostruke uloge cijene u procesu kupnje odnosno načina kako potrošači percipiraju cijenu, a što se može smatrati bitnom odrednicom cjenovne strategije poduzeća.
\end{abstract}

KLJUČNE RIJEČI: odnos cijene i kvalitete, cjenovna osjetljivost potrošača, dvostruka uloga cijene, elektronički proizvodi.

ABSTRACT: During their buying decision-making process, consumers tend to perceive the price of the product in its dual role: as a monetary sacrifice (more price sensitive consumers) and as a signal of product quality (less price sensitive consumers). Consumers' price sensitivity, as well as their price-quality perceptions, may vary across product categories. Hence, the aim of the paper was to determine the consumers' price sensitivity and also their tendency to use a price as a product quality cue when purchasing electronic products

Izv. prof. dr. sc. Sunčana Piri Rajh, izvanredna profesorica, Sveučilište u Zagrebu, Ekonomski fakultet, Katedra za marketing, Trg J. F. Kennedyja 6, 10000 Zagreb, e-mail: spiri@net.efzg.hr.

Lidija Lijović, univ. bacc. oec., e-mail: lidija.lijovic@gmail.com. 
(smartphones, laptops, and TV sets). Using the online survey method, the empirical research has been conducted on a convenient sample of 123 respondents who use the aforementioned product categories. Research results showed that there are two groups of products that differ regarding the relative importance of two analyzed variables (price-quality relationship perception and consumer price sensitivity) in purchasing process. This research study indicates the importance of understanding the dual role of a price in a purchasing situation, which can be considered as an important determinant of a company's pricing strategy.

KEY WORDS: price-quality relationship, consumer price sensitivity, dual role of price, electronic products.

\section{UVOD}

Prilikom odlučivanja o kupnji proizvoda potrošači razmatraju njihova pojedina obilježja. Jedno od obilježja koje značajno utječe na ponašanje potrošača (Han, Gupta i Lehmann, 2001.), a koje potrošači mogu dvojako percipirati te posljedično tome i koristiti kao kriterij kupovnog odabira, jest cijena.

Cijena je za potrošače, prije svega, primarni novčani trošak kojemu se izlažu u procesu kupnje (Bender, 1964.; Snoj, Pisnik Korda i Mumel, 2004.) i u tome kontekstu za potrošače predstavlja ograničavajuću varijablu koja negativno utječe na vjerojatnost kupnje jer plaćanjem određene cijene potrošaču se smanjuje razina njegova diskrecijskog dohotka (Erickson i Johansson, 1985.; Lichtenstein, Ridgway i Netemeyer, 1993.; Verma i Gupta, 2004.; Bornemann i Homburg, 2011.). Međutim, potrošači ne odabiru uvijek proizvod najniže cijene (Völckner, 2008.), što ukazuje na činjenicu da cijenu potrošači ne moraju nužno percipirati samo kao ekonomski gubitak. Dosad su provedena brojna istraživanja koja su pokazala da su potrošači spremni platiti i višu cijenu proizvoda jer istu povezuju s višom kvalitetom toga proizvoda $^{1}$, što dovodi do zaključka da cijena može i pozitivno utjecati na vjerojatnost kupnje (Erickson i Johansson, 1985.; Rao i Monroe, 1988.; Lichtenstein, Ridgway i Netemeyer, 1993.; Suri, Manchanda i Kohli, 2000.; Völckner, 2008.). Drugim riječima, potrošači su skloni osloniti se na cijenu kako bi donijeli zaključak o kvaliteti promatranoga proizvoda. Ovo upućuje na zaključak da se cijena ne treba smatrati jednodimenzionalnim obilježjem proizvoda, jer je u pitanju kriterij koji za potrošača u procesu kupnje može imati dvostruku ulogu.

Ovu dvostruku ulogu cijene u svojim su istraživanjima testirali brojni autori. Tako na primjer, Völckner (2008.) ukazuje na troškovnu i informacijsku ulogu cijene, dok Lichtenstein, Ridgway i Netemeyer (1993.) govore o negativnoj i pozitivnoj ulozi cijene, naglašavajući pritom da je u onim situacijama kada potrošači cijenu percipiraju kao trošak, njezina uloga negativna; i obrnuto, u situacijama kada potrošači cijenu percipiraju kao pokazatelja kvalitete, njezina je uloga pozitivna. Ovdje treba istaknuti da se pojam negativne odnosno pozitivne uloge cijene odnosi na njezin utjecaj na vjerojatnost kupnje (Lichtenstein, Ridgway i Netemeyer, 1993.; Moore, McGowan Kennedy i Fairhurst, 2003.).

U ovome kontekstu Tellis i Gaeth (1990.) ističu da postoje i oni potrošači koji su skloni odabrati upravo onu marku koju obilježava najviša cijena, pretpostavljajući da će na taj način doći do proizvoda kojega obilježava i najviša očekivana kvaliteta; ovakvo ponašanje navedeni autori nazivaju ,traženjem (najviše) cijene“ (engl. price-seeking). 
Osim što se razlikuju po tome kako će u određenim situacijama percipirati cijenu (primarno kao novčani trošak ili kao informaciju o kvaliteti proizvoda), potrošači se razlikuju i u tome koliku važnost uopće pridaju cijeni kada odlučuju o kupnji proizvoda, a što se može objasniti konceptom njihove cjenovne osjetljivosti (Nagle i Holden, 2002., navedeno u: Taher i El Basha, 2006.).

Prema Goldsmithu i Newellu (1997.), potrošači koji su više cjenovno osjetljivi, cijenu će primarno percipirati kao novčani trošak budući da će njihova potražnja za proizvodom biti manja kako cijena toga proizvoda raste. Nadalje, potrošači koji su skloniji koristiti cijenu kao informaciju o kvaliteti proizvoda, manje su cjenovno osjetljivi u kupnji toga proizvoda (Nagle i Holden, 2002.). Sve ovo upućuje na zaključak da se potrošači u kupnji doista razlikuju i s obzirom na pozornost koju posvećuju cijeni kao obilježju proizvoda, ali i s obzirom na značenje koje joj pridaju i kako na nju reagiraju, a što u svojemu radu ističu Dickson i Sawyer (1990.).

Budući da potrošaču cijena pruža informaciju i o novčanome trošku, ali i o kvaliteti proizvoda (Suri, Manchanda i Kohli, 2000.), pri čemu sklonost potrošača da cijenu koriste kao pokazatelja kvalitete može značajno varirati ovisno i o kategoriji proizvoda (npr., Monroe i Krishnan, 1985., navedeno u: Lichtenstein i Burton, 1989.; Zeithaml, 1988.), osnovni je cilj rada istražiti u kojoj se mjeri potrošači oslanjaju na cijenu kao pokazatelja kvalitete te koliko su cjenovno osjetljivi u kupnji tri odabrane kategorije elektroničkih proizvoda koji predstavljaju trajna potrošna dobra. Štoviše, treba istaknuti i to da su dosadašnja istraživanja u manjoj mjeri testirala povezanost kategorije proizvoda i cjenovne osjetljivosti potrošača, ali i da su u najvećoj mjeri predmetom istraživanja bili obuhvaćeni proizvodi široke potrošnje koji se kupuju na dnevnoj, tjednoj ili mjesečnoj osnovi (Wakefield i Inman, 2003.). Stoga će se ovim radom ujedno nastojati smanjiti navedeni jaz u postojećoj literaturi. Konačno, budući da su dosadašnja istraživanja (navedena u: Völckner i Hofmann, 2007.) pokazala i to da su i cjenovna osjetljivost potrošača i njihova sklonost korištenju cijene kao pokazatelja kvalitete uvjetovana kategorijom proizvoda koji pripadaju trajnim potrošnim dobrima, postavljeni cilj ovoga rada može se smatrati opravdanim.

Rad je organiziran u pet poglavlja. Nakon uvoda, slijedi teorijski okvir čija je svrha opisati odnos cijene i kvalitete te koncept cjenovne osjetljivosti potrošača. Nakon toga, slijedi prikaz empirijskoga istraživanja, opis metodologije te prikaz rezultata istraživanja i diskusija. Rad završava zaključkom, u okviru kojega se iznose zaključna razmatranja, ograničenja istraživanja, kao i smjernice za buduća istraživanja. Nakon zaključka slijedi popis korištene literature. U prilogu rada nalazi se tablica u okviru koje su prikazane mjerne ljestvice korištene u empirijskome istraživanju, kao i pripadajući izvori.

\section{TEORIJSKI OKVIR}

\subsection{Odnos cijene i kvalitete}

Prema Finlayu, Hackmannu i Schwarzu (1996., str. 71), „cijena i kvaliteta proizvoda predstavljaju jedne od najvažnijih strateških varijabli u okviru marketinškog miksa“. I dok se kvaliteta smatra značajnim kriterijem kupovnog odabira, štoviše i primarnom odrednicom zadovoljstva potrošača (Fornell et al., 1996., navedeno u: Cronin, Jr., Brady i Hult, 
2000., str. 195), cijena se smatra jednom od „ključnih marketinških varijabli koje potrošaču signaliziraju kvalitetu“ (Brucks, Zeithaml i Naylor, 2000., str. 364). Osnovni razlog zašto potrošači očekuju da će viša cijena rezultirati višom kvalitetom proizvoda, jest taj da cijenu smatraju „konkretnom manifestacijom troškova“ (Finlay, Hackmann i Schwarz, 1996., str. 72), a isti su, prema vjerovanju potrošača, viši kada je u pitanju proizvodnja kvalitetnijih proizvoda (Imkamp, 2008.). ${ }^{2}$

U određenim kupovnim situacijama potrošači su doista suočeni s vlastitom nesigurnošću po pitanju kvalitete proizvoda kojega razmatraju; to je osobito izraženo kada prije kupnje ne mogu isprobati proizvod ili koristiti uzorak proizvoda (Nelson, 1970.); zatim, kada su u pitanju proizvodi koji se ne kupuju često, a njihova je cijena relativno visoka (Nagle i Holden, 1995.) odnosno kada općenito nemaju dovoljno znanja i iskustva s promatranom kategorijom proizvoda (Rao i Monroe, 1988.). Stoga, kako bi smanjili nesigurnost, potrošači koriste određene pokazatelje koji im signaliziraju kvalitetu proizvoda. Iako na potrošačevu percepciju kvalitete proizvoda mogu utjecati i neka druga obilježja, kao što su imidž marke, imidž zemlje podrijetla proizvoda i imidž prodajnoga mjesta (Zeithaml, 1988.; Rao i Monroe, 1989.; Dodds, Monroe i Grewal, 1991.; Agarwal i Teas, 2001.), većina se dosadašnjih istraživanja bavila utjecajem razine cijene proizvoda na percepciju kvalitete proizvoda (Brucks, Zeithaml i Naylor, 2000.), pri čemu su brojna od njih potvrdila pozitivnu, ali i slabu vezu cijene i kvalitete u slučaju proizvoda namijenjenih krajnjim potrošačima (Imkamp, 2008.).

Ipak, Yan i Sengupta (2011.) ukazuju na rezultate onih istraživanja koja potvrđuju da postoji i nekonzistentnost u jačini te veze između ove dvije promatrane varijable. Tako je npr., istraživanje koje su proveli Szybillo i Jacoby (1974., navedeno u: Yan i Sengupta, 2011.) pokazalo da značajnost veze između cijene i kvalitete može ovisiti i o prisutnosti ostalih informacija o proizvodu koje su potrošaču na raspolaganju tijekom procesa odlučivanja o kupnji i koje mu olakšavaju zaključivanje o kvaliteti promatranoga proizvoda, kada cijena zapravo gubi na svojemu značaju kao primarnog pokazatelja kvalitete, a što su u svojemu radu istaknuli i Erickson i Johansson (1985.). Međutim, Kardes et al. (2004., 2008., navedeno u: Yan i Sengupta, 2011.) u svojemu su istraživanju pokazali da unatoč tome što potrošačima na raspolaganju mogu stajati i dodatne informacije o proizvodu, potrošači i dalje mogu biti skloni osloniti se upravo na cijenu kao primarnog pokazatelja kvalitete proizvoda. Sve ovo upućuje na zaključak da jačina veze između cijene i kvalitete može biti uvjetovana i kategorijom proizvoda.

\subsection{Cjenovna osjetljivost potrošača}

Cjenovnu osjetljivost potrošača Tellis (1988., str. 331) definira kao „stupanj do kojega se potrošači razlikuju u svojim kupnjama proizvoda čija se cijena mijenja.“ Slično objašnjenje pojma cjenovne osjetljivosti daju Goldsmith i Newell (1997.), koji naglašavaju da cjenovna osjetljivost potrošača opisuje kako pojedini potrošač reagira na različite razine

Ovdje je korisno istaknuti da unatoč tome što među potrošačima postoji tendencija da višu cijenu povezuju s višom kvalitetom (pretpostavljajući da je ona rezultat viših troškova proizvodnje), postoje i ona istraživanja na koja u svojemu radu upućuju Finlay, Hackmann i Schwarz (1996., str. 72), a koja su rezultirala spoznajom da poboljšanja u kvaliteti proizvoda ne moraju nužno rezultirati povećanjem troškova. 
cijene i promjene tih razina cijene. Nagle i Holden (2002., navedeno u: Taher i El Basha, 2006.), cjenovnu osjetljivost potrošača promatraju kao važnost koju potrošači pridaju cijeni u procesu odlučivanja o kupnji proizvoda, dok Dominique-Ferreira, Vasconcelos i Proença (2016., str. 329), pod pojmom cjenovne osjetljivosti potrošača podrazumijevaju i „kako se potrošači osjećaju vezano uz plaćanje određene cijene proizvoda“. Koncept cjenovne osjetljivosti potrošača upućuje na to da je u pitanju individualno obilježje potrošača te da među njima postoji razlika s obzirom na važnost koju pridaju cijeni u kupovnome procesu.

Dosadašnja su istraživanja (npr., Ainslie i Rossi, 1998.; Erdem i Sun, 2002.; Iyengar et al., 2003.; Singh et al., 2005.; Song i Chintagunta, 2006., a na koja u svojemu radu upućuju Duvvuri, Ansari i Gupta, 2007.) pokazala da će potrošači koji su izrazito cjenovno osjetljivi u slučaju jedne kategorije proizvoda, vrlo vjerojatno biti izrazito cjenovno osjetljivi i u slučaju druge proizvodne kategorije, što znači da je cjenovna osjetljivost potrošača obilježje koje je u pozitivnoj korelaciji s različitim kategorijama proizvoda. Treba istaknuti da su ova istraživanja promatrala vezu između cjenovne osjetljivosti potrošača i različitih kategorija prehrambenih i neprehrambenih proizvoda koji se kupuju na dnevnoj, tjednoj ili mjesečnoj osnovi. Istraživanje provedeno za potrebe ovoga rada imalo je cilj utvrditi kakva je cjenovna osjetljivost potrošača u slučaju kategorija elektroničkih proizvoda ${ }^{3}$, dakle trajnih potrošnih dobara koji se kupuju rjeđe i čiji je očekivani rok trajanja dulji od dvije godine (Finlay, Hackmann i Schwarz, 1996.) te koji pretpostavljaju relativno visoku razinu uključenosti potrošača u kupovnome procesu zbog više razine percipiranog kupovnog, prije svega funkcionalnoga i financijskoga rizika.

Nadalje, Wakefield i Inman (2003., navedeno u: Aroean i Michaelidou, 2014.) u svojemu su radu također istaknuli da će cjenovna osjetljivost potrošača biti različita i ovisno o tome zadovoljava li potrošač kupnjom i upotrebom proizvoda svoje emocionalne ili funkcionalne potrebe te da će u tome kontekstu biti cjenovno osjetljiviji ako su u pitanju proizvodi čijom se upotrebom postiže, prije svega, funkcionalna korist. Budući da su predmet istraživanja za potrebe ovoga rada također bili proizvodi za koje se može pretpostaviti da pružaju različite razine funkcionalne koristi, u radu se testira koliko su potrošači cjenovno osjetljivi u kupnji istih te postoje li razlike u cjenovnoj osjetljivosti potrošača ovisno o promatranoj kategoriji elektroničkog proizvoda.

\section{METODOLOGIJA ISTRAŽIVANJA}

\subsection{Odabir kategorija proizvoda i cilj istraživanja}

U istraživanju su bile uključene tri kategorije elektroničkih proizvoda: pametni telefoni, prijenosna računala i televizori. Odluka o odabiru upravo ovih kategorija proizvoda temeljila se na rezultatima istraživanja koje u svojemu radu navode Völckner i Hofmann (2007.). Ovi autori, naime, ističu da su dosadašnja istraživanja (npr., Bijmolt et al., 2005., navedeno u: Völckner i Hofmann, 2007.) ukazala na to da će cjenovna osjetljivost potrošača biti veća upravo u slučaju trajnih potrošnih dobara, dakle proizvoda koji se ne kupuju rutinski i po navici, već koji podrazumijevaju veću uključenost potrošača u kupovnome

U okviru Metodologije istraživanja detaljnije je obrazložen odabir kategorije elektroničkih proizvoda. 
procesu i pomnije razmatranje kupovne odluke. No, s druge strane, postoje i istraživanja (npr., Lichtenstein i Burton, 1989., navedeno u: Völckner i Hofmann, 2007.) koja su pokazala da su upravo u slučaju trajnih potrošnih dobara potrošači skloniji osloniti se na cijenu kao valjanog pokazatelja kvalitete proizvoda. Drugim riječima, radi se zapravo o proizvodima kod kojih visoka cijena ukazuje potrošaču i na visok novčani trošak kojemu će biti izložen u slučaju odabira toga proizvoda, ali istodobno ta cijena može ukazivati i na visoku kvalitetu proizvoda (Suri, Manchanda i Kohli, 2000.). Razlog zašto je izglednije da će se potrošači prilikom kupnje ovakvih proizvoda osloniti na cijenu kako bi zaključili o kvaliteti istih, može se objasniti činjenicom da su u pitanju proizvodi koji kod potrošača mogu izazvati veću percepciju kupovnoga rizika ${ }^{4}$, jer su to proizvodi koje potrošači kupuju povremeno i stoga je njihovo znanje o proizvodu slabije u odnosu na znanje o proizvodima široke potrošnje koji se kupuju na dnevnoj, tjednoj ili mjesečnoj osnovi. Riječ je zapravo o proizvodima koje potrošači nerijetko percipiraju i kao tehnički složene i čiju kvalitetu im je teže procijeniti u odnosu na proizvode koje kupuju često i s čijim su obilježjima relativno dobro upoznati (Völckner i Hofmann, 2007.).

Budući da je iz rezultata prethodnih istraživanja razvidno da su i cjenovna osjetljivost potrošača i njihova sklonost korištenju cijene kao pokazatelja kvalitete proizvodno specifična, postavlja se istraživačko pitanje: Koliko su potrošači u procesu kupnje odabranih kategorija elektroničkih proizvoda cjenovno osjetljivi te koliko su skloni osloniti se na cijenu kao pokazatelja kvalitete proizvoda?

\subsection{Opis mjernoga instrumenta}

Empirijsko istraživanje provedeno je metodom online ankete. Kao mjerni instrument korišten je visokostrukturirani anketni upitnik koji je s obzirom na istraživane kategorije proizvoda (pametni telefon, prijenosno računalo i televizor) bio podijeljen na tri dijela. $\mathrm{Na}$ početku svakoga dijela upitnika bilo je postavljeno eliminacijsko pitanje o korištenju pojedine kategorije proizvoda. Ako su na sva tri pitanja bili dani potvrdni odgovori, ispitanik je nastavio popunjavati anketni upitnik. Upitnik je sadržavao deset tvrdnji kojima se mjerila percepcija odnosa cijene i kvalitete i cjenovna osjetljivost potrošača (za svaku od promatranih kategorija proizvoda). Četiri tvrdnje koje su testirale percepciju odnosa cijene i kvalitete bile su preuzete iz rada čiji su autori Lichtenstein, Ridgway i Netemeyer (1993.), dok se cjenovna osjetljivost potrošača mjerila pomoću šest tvrdnji, od kojih su tri tvrdnje bile preuzete iz rada čiji su autori Anić, Piri Rajh i Rajh $(2010 \text {. })^{5}$, a tri su tvrdnje bile preuzete iz rada čiji su autori Wakefield i Inman (2003.) Ispitanici su svoj stupanj slaganja s navedenim tvrdnjama izražavali putem Likertove ljestvice s pet stupnjeva, pri čemu je 1 značilo „uopće se ne slažem“, a 5 ,u potpunosti se slažem“. Sve tvrdnje korištene u istraživanju navedene su u tablici 5., u Prilogu rada. Konačno, u upitniku je bilo postavljeno i pet pitanja koja su se odnosila na demografska obilježja ispitanika.

U ovome kontekstu, Dodds (1991.) navodi da je izglednija pojava percipiranog kupovnog rizika u slučaju onih proizvoda za koje potrošačima nedostaje prethodno kupovno i iskustvo korištenja proizvoda (isti se, dakle, kupuju po prvi puta) ili to iskustvo postoji, ali je ono ograničeno.

Riječ je o hrvatskome prijevodu tvrdnji preuzetih iz rada: Sproles, G. B., Kendall, E. L. (1986.): „A methodology for profiling consumer decision-making styles“, The Journal of Consumer Affairs, 20 (2), str. 6779. 


\subsection{Opis uzorka}

Empirijsko istraživanje provedeno je na namjernome, prigodnome uzroku veličine 123 ispitanika koji koriste sve tri promatrane kategorije elektroničkih proizvoda. Struktura uzorka prikazana je u tablici 1.

Tablica 1. Struktura uzorka $(n=123)$

\begin{tabular}{|l|r|}
\hline OBILJEŽJE ISPITANIKA & \multicolumn{1}{|c|}{$\%$} \\
\hline Spol & \\
Muški & 45,5 \\
Ženski & 54,5 \\
\hline Dob & \\
$18-25$ & 63,3 \\
$26-35$ & 15,8 \\
$36-45$ & 14,2 \\
$46-55$ & 5,0 \\
$56-65$ & 1,7 \\
66 i više & 0,0 \\
\hline Završena razina obrazovanja & \\
Osnovna škola & 0,8 \\
Srednja škola & 47,9 \\
Preddiplomski studij & 39,7 \\
Diplomski studij & 8,3 \\
Magisterij znanosti/Doktorat & 3,3 \\
\hline Radni status & \\
Student/ica ili učenik/ica & 69,4 \\
Zaposlen/a & 25,6 \\
Nezaposlen/a & 4,1 \\
Umirovljenik/ica & 0,8 \\
\hline Prosječni mjesečni prihodi kućanstva (u HRK) \\
Do 3000 & 5,7 \\
3001-6000 & 18,7 \\
6001-9000 & 35,8 \\
9001 kuna i više & 7,3 \\
\hline Ne želim odgovoriti & \\
\hline
\end{tabular}

Izvor: istraživanje.

Kao što je vidljivo iz tablice 1., od ukupnoga broja ispitanika $(n=123)$, u istraživanju su bili uključeni ispitanici oba spola (45,5\% muških i 54,5 \% ženskih ispitanika), pri čemu su, ako se promotri radni status ispitanika, istraživanjem u najvišemu postotku bili obuhvaćeni pripadnici studentske populacije $(69,4 \%)$. Što se tiče dobi, najveći broj ispitanika nalazi se u dobnoj skupini između 18 i 25 godina $(63,3 \%)$, dok se približno jednak postotak ispitanika javlja u sljedeće dvije dobne skupine $(15,8 \%$ ispitanika koji pripadaju dobnoj skupini od 26 do 35 godina, u odnosu na 14,2 \% ispitanika koji pripadaju dobnoj skupini od 36 do 45 godina). Tek nešto manje od $7 \%$ ispitanika pripada dobnoj skupini od 46 do 65 godina. Razlog ovakve dobne strukture ispitanika vjerojatno se može objasniti činjenicom što je istraživanje 
provedeno primjenom online anketnoga istraživanja odnosno pretpostavkom da se mlađi i ispitanici mlađe srednje dobi više služe internetom od ispitanika starijih dobnih skupina. Što se tiče postignutoga formalnog obrazovanja sudionika istraživanja, najveći postotak ispitanika ima završeno srednjoškolsko obrazovanje (približno $48 \%$ ), a nakon toga slijede ispitanici sa završenim preddiplomskim studijem (približno $40 \%$ ). Konačno, najveći broj ispitanika dolazi iz kućanstava koja ostvaruju prosječni mjesečni prihod između 6.001,00 kuna i 9.000,00 kuna (približno $36 \%$ ), zatim slijedi 32,5\% onih ispitanika čija kućanstva obilježavaju prosječni mjesečni prihodi iznad 9.000,00 kuna, dok tek nešto manje od četvrtine ispitanika (njih 24,4 $\%)$ dolazi iz kućanstava s prosječnim mjesečnim prihodima od 6.000,00 kuna i manje.

\section{REZULTATI ISTRAŽIVANJA I DISKUSIJA}

Prilikom analize prikupljenih podataka najprije se pristupilo utvrđivanju psihometrijskih obilježja primijenjenih mjernih ljestvica odnosno njihove valjanosti i pouzdanosti. Primjenom eksplorativne faktorske analize procijenjena je konvergentna i diskriminantna valjanost korištenih mjernih ljestvica, dok je izračunom Cronbach alfa koeficijenta procijenjena njihova pouzdanost.

Eksplorativnom faktorskom analizom izdvojena su dva faktora, pri čemu je kao kriterij odabira broja faktora primijenjeno Kaiser-Guttmanovo pravilo prema kojemu se zadržavaju oni faktori kojima je svojstvena vrijednost veća od 1. Izdvojeni faktori objašnjavaju u slučaju proizvodne kategorije „pametni telefon“ 65,6 \% ukupne varijance, u slučaju kategorije „prijenosno računalo“ 69,5 \% ukupne varijance te u slučaju kategorije „televizor“ $69,1 \%$ ukupne varijance.

Kao metoda ekstrakcije faktora primijenjena je metoda glavnih komponenti, dok je kao metoda rotacije primijenjena varimax raw rotacija. Rezultirajuća faktorska struktura prikazana je u tablici 2 .

Tablica 2. Faktorska struktura nakon varimax rotacije faktora

\begin{tabular}{|c|c|c|c|c|c|c|}
\hline $\begin{array}{c}\text { KATEGORIJA } \\
\text { PROIZVODA }\end{array}$ & \multicolumn{2}{|c|}{ Pametni telefon } & \multicolumn{2}{c|}{ Prijenosno računalo } & \multicolumn{2}{c|}{ Televizor } \\
\hline TVRDNJA & Faktor 1 & Faktor 2 & Faktor 1 & Faktor 2 & Faktor 1 & Faktor 2 \\
\hline i_1 & $\mathbf{0 , 8 6}$ & 0,01 & $\mathbf{0 , 8 7}$ & 0,00 & $\mathbf{0 , 8 9}$ & $-0,01$ \\
\hline i_2 & $\mathbf{0 , 8 6}$ & $-0,07$ & $\mathbf{0 , 8 8}$ & 0,01 & $\mathbf{0 , 8 4}$ & $-0,01$ \\
\hline i_3 & $\mathbf{0 , 8 8}$ & $-0,03$ & $\mathbf{0 , 8 7}$ & $-0,01$ & $\mathbf{0 , 8 7}$ & $-0,02$ \\
\hline i_4 & $\mathbf{0 , 7 5}$ & $-0,00$ & $\mathbf{0 , 8 0}$ & 0,10 & $\mathbf{0 , 8 0}$ & 0,05 \\
\hline i_8 & 0,05 & $\mathbf{0 , 6 8}$ & $-0,01$ & $\mathbf{0 , 8 4}$ & 0,01 & $\mathbf{0 , 8 5}$ \\
\hline i_9 & $-0,09$ & $\mathbf{0 , 8 3}$ & 0,07 & $\mathbf{0 , 8 2}$ & 0,02 & $\mathbf{0 , 7 5}$ \\
\hline i_10 & 0,00 & $\mathbf{0 , 7 8}$ & $-0,00$ & $\mathbf{0 , 7 4}$ & $-0,03$ & $\mathbf{0 , 8 0}$ \\
\hline
\end{tabular}

Izvor: istraživanje.

Rezultirajuća faktorska struktura, koja je prikazana u tablici 2., upućuje na zaključak da sedam tvrdnji posjeduju svojstvo konvergentne valjanosti (tvrdnje pokazuju visoko faktorsko opterećenje na odgovarajućim faktorima) i diskriminantne valjanosti (tvrdnje pokazuju niska faktorska opterećenja na ostalim faktorima). 
Riječ je o sljedećim tvrdnjama: „Općenito gledano, što je viša cijena (...), veća je $i$ njegova kvaliteta“, „Izreka 'što platiš - to i dobiješ, općenito je točna kada je u pitanju (...)“, „Cijena (...) dobar je pokazatelj njegove kvalitete“, „Uvijek moraš platiti više kako bi dobio/la najbolji (...)“. Navedene četiri tvrdnje mjere odnos cijene i kvalitete te su preuzete i prilagođene iz rada čiji su autori Lichtenstein, Ridgway i Netemeyer (1993.).

Nadalje, tri tvrdnje ("Spreman/na sam uložiti dodatan trud kako bih pronašao/la najnižu cijenu za (...)“, „Osjetljiv/a sam na razlike u cijenama (...)“, te „Promijenio/la bih planiranu odluku o kupovini (...) ukoliko bih pronašao/la proizvod niže cijene"), mjere cjenovnu osjetljivost potrošača, a preuzete su iz rada čiji su autori Wakefield i Inman (2003.).

Konačno, tri su tvrdnje preuzete iz rada čiji su autori Anić, Piri Rajh i Rajh (2010.), a koji su preveli izvorne tvrdnje razvijene od strane Sprolesa i Kendall (1986.). Ovim se tvrdnjama također mjerila cjenovna osjetljivost potrošača, no budući da su faktorska opterećenja za ove tvrdnje bila preniska na pripadajućemu faktoru, ove tvrdnje su isključene iz daljnje analize. Riječ je o sljedećim tvrdnjama: „Jeftiniji (...) bi uglavnom bio moj izbor“, „Prilikom kupnje (...) nastojao/la bih pronaći najbolju vrijednost za svoj novac“ i „(...) kupovaolla bih koliko je god to moguće po sniženim cijenama na akcijama“.

Nakon provedene eksplorativne faktorske analize, utvrđena je pouzdanost primijenjenih mjernih ljestvica izračunom Cronbach alfa koeficijenata. S obzirom da se navedeni koeficijenti u slučaju mjerne ljestvice „Odnos cijene i kvalitete“ kreću između 0,86 i 0,88, dok se u slučaju druge promatrane mjerne ljestvice „Cjenovna osjetljivost potrošača“ nalaze u rasponu od 0,64 do 0,72 (tablica 3.), ovo dovodi do zaključka o prihvatljivoj razini pouzdanosti korištenih mjernih ljestvica (Kline, 1998.).

Tablica 3. Cronbach alfa koeficijenti

\begin{tabular}{|c|c|c|c|}
\hline \multicolumn{5}{|c|}{ Cronbach alfa koeficijenti } \\
\hline KATEGORIJA PROIZVODA & Pametni telefon & Prijenosno računalo & Televizor \\
\hline MJERNA LJESTVICA & & & $\mathbf{0 , 8 7}$ \\
\hline Odnos cijene i kvalitete & $\mathbf{0 , 8 6}$ & $\mathbf{0 , 8 8}$ & $\mathbf{0 , 7 2}$ \\
\hline Cjenovna osjetljivost potrošača & $\mathbf{0 , 6 4}$ & $\mathbf{0 , 7 2}$ & \\
\hline
\end{tabular}

Izvor: istraživanje.

U tablici 4. prikazane su aritmetičke sredine i standardne devijacije za analizirane varijable po promatranim kategorijama proizvoda.

Tablica 4. Aritmetičke sredine i standardne devijacije

\begin{tabular}{|c|c|c|c|c|c|c|}
\hline $\begin{array}{c}\text { KATEGORIJA } \\
\text { PROIZVODA }\end{array}$ & \multicolumn{2}{|c|}{ Pametni telefon } & \multicolumn{2}{c|}{ Prijenosno računalo } & \multicolumn{2}{c|}{ Televizor } \\
\hline VARIJABLA & $\begin{array}{c}\text { Aritmetička } \\
\text { sredina }\end{array}$ & $\begin{array}{c}\text { Standardna } \\
\text { devijacija }\end{array}$ & $\begin{array}{c}\text { Aritmetička } \\
\text { sredina }\end{array}$ & $\begin{array}{c}\text { Standardna } \\
\text { devijacija }\end{array}$ & $\begin{array}{c}\text { Aritmetička } \\
\text { sredina }\end{array}$ & $\begin{array}{c}\text { Standardna } \\
\text { devijacija }\end{array}$ \\
\hline $\begin{array}{c}\text { Odnos cijene i } \\
\text { kvalitete }\end{array}$ & 3,52 & 0,824825 & 3,91 & 0,728397 & 3,73 & 0,799423 \\
\hline $\begin{array}{c}\text { Cjenovna osjetljivost } \\
\text { potrošača }\end{array}$ & 3,86 & 0,740362 & 4,02 & 0,727865 & 3,89 & 0,743725 \\
\hline
\end{tabular}

Izvor: istraživanje. 
Kako bi se ispitalo postojanje statistički značajnih razlika između prikazanih aritmetičkih sredina, proveden je t-test. Rezultati t-testa ukazuju da između varijabli odnosa cijene i kvalitete i cjenovne osjetljivosti potrošača postoji statistički značajna razlika $(p<0,05)$ samo u slučaju kategorije proizvoda pametnih telefona, dok kod ostale dvije promatrane proizvodne kategorije razlike između ove dvije varijable nisu statistički značajne.

Što se tiče statistički značajne razlike između varijable odnosa cijene i kvalitete za različite proizvode, rezultati t-testa ukazuju da postoji statistički značajna razlika $(\mathrm{p}<0,05)$ kod ove varijable za sve tri kategorije proizvoda, pri čemu ispitanici u najvećoj mjeri koriste cijenu kao pokazatelj kvalitete u slučaju prijenosnih računala, a u najmanjoj mjeri u slučaju pametnih telefona.

Nadalje, rezultati t-testa ukazuju da ne postoji statistički značajna razlika $(\mathrm{p}<0,05)$ u cjenovnoj osjetljivosti potrošača između proizvoda pametnih telefona i televizora, ali postoji između cjenovne osjetljivosti u slučaju prijenosnih računala i ostale dvije kategorije proizvoda. Pritom je ujedno cjenovna osjetljivost potrošača izraženija u slučaju kategorije proizvoda prijenosnih računala.

Navedeni nalazi istraživanja upućuju na zaključak da se kategorije proizvoda razlikuju s obzirom na relativnu važnost dvije analizirane varijable; odnosa cijene i kvalitete, $\mathrm{s}$ jedne strane te cjenovne osjetljivosti potrošača, s druge strane. Drugim riječima, u istraživanju su identificirane dvije skupine kategorija proizvoda koje se razlikuju s obzirom na relativnu važnost ove dvije analizirane varijable u procesu kupnje. Kod jedne skupine proizvoda cijena je u istoj mjeri i pokazatelj kvalitete i pokazatelj troška, dok je kod druge skupine proizvoda cijena u većoj mjeri pokazatelj troška nego kvalitete. Za pretpostaviti je da bi obuhvaćanjem većeg broja proizvoda bilo moguće identificirati i treću skupinu proizvoda kod koje je cijena za potrošače prije svega pokazatelj kvalitete, a tek potom pokazatelj novčanoga troška. Čimbenici koji utječu da se određena kategorija proizvoda nađe u jednoj, drugoj ili trećoj skupini s obzirom na cjenovnu osjetljivost potrošača i njihovu percepciju cijene kao pokazatelja kvalitete vjerojatno su dominantno u području obilježja samih proizvoda, koristi koje se ostvaruju korištenjem tih proizvoda, strukture tržišta, pa sve do obilježja ciljnih tržišnih segmenata te njihove upoznatosti s kategorijom proizvoda.

Provedeno istraživanje također upućuje na zaključak da postoji veća varijacija u varijabli odnosa cijene i kvalitete među različitim kategorijama proizvoda, dok je varijacija u varijabli cjenovne osjetljivosti manje izražena među različitim kategorijama proizvoda. Moguće objašnjenje ovakvoga nalaza istraživanja može se pronaći u činjenici da je varijabla odnosa cijene i kvalitete pod većim utjecajem različitih specifičnih obilježja proizvoda i pripadajućega tržišta.

\section{ZAKLJUČAK}

U kupnji proizvoda potrošači mogu različito reagirati na cijenu te joj različito pristupiti kao kriteriju kupovnoga odabira. Stoga je cilj rada bio istražiti u kojoj se mjeri potrošači oslanjanju na cijenu kao pokazatelja kvalitete te koliko su cjenovno osjetljivi u kupnji odabranih kategorija elektroničkih proizvoda, i to pametnih telefona, prijenosnih računala i televizora. 
Rezultati istraživanja pokazali su da postoje dvije skupine kategorija proizvoda koje se razlikuju s obzirom na relativnu važnost dvije istraživane varijable (odnosa cijene i kvalitete i cjenovne osjetljivosti potrošača) u procesu kupnje. Kod jedne skupine kategorija proizvoda cijena se u istoj mjeri percipira i kao pokazatelj kvalitete i kao pokazatelj troška, dok se kod druge skupine, cijena u većoj mjeri promatra kao pokazatelj troška nego kao pokazatelj kvalitete. Za pretpostaviti je da je na tržištu moguće identificirati i kategorije proizvoda kod kojih je cijena u većoj mjeri pokazatelj kvalitete, a u manjoj mjeri pokazatelj troška. Stoga bi kao jedna od smjernica za buduća istraživanja bila ta da se obuhvati veći broj različitih kategorija proizvoda kako bi se dodatno istražila relativna važnost varijabli odnosa cijene i kvalitete i cjenovne osjetljivosti potrošača u procesu kupnje te kako bi se ispitalo postojanje identificiranih skupina proizvoda i u drugim kategorijama proizvoda.

Prilikom interpretacije rezultata istraživanja, treba imati u vidu i postojeća ograničenja istraživanja, a koja se mogu smatrati dodatnim smjernicama za buduća istraživanja. Ograničenja ovoga istraživanja su u prvome redu povezana s veličinom i vrstom uzorka. Primijenjeni uzorak bio je namjeran, prigodni i premda su ga činili stvarni korisnici sve tri promatrane kategorije elektroničkih proizvoda, ipak su u istraživanju većinom sudjelovali mlađi korisnici promatranih proizvodnih kategorija, i to pripadnici studentske populacije te stoga, da bi se rezultati mogli generalizirati, potrebno ih je dodatno verificirati na reprezentativnome uzorku. Međutim, treba istaknuti i to da se i uključivanje studenata, ali i uključivanje bilo kojih drugih sudionika u istraživanje, može smatrati opravdanim kada se istraživanjem testira određena teorija (Mook, 1983.; navedeno u: Peterson i Merunka, 2014.), kao što je to slučaj i u ovome radu. Također, treba imati u vidu da su istraživanjem obuhvaćene tek tri kategorije, i to elektroničkih proizvoda. Daljnja bi istraživanja, u svrhu generalizacije rezultata, trebala uključiti i druge kategorije proizvoda koje potrošači ne kupuju često ili im nedostaje prethodno kupovno iskustvo koje bi im u trenutku donošenja kupovne odluke poslužilo kao svojevrsna referentna točka u zaključivanju o kvaliteti promatranoga proizvoda, ali i one proizvode koje kupuju na dnevnoj, tjednoj ili mjesečnoj osnovi. Također, buduća bi istraživanja trebala uključiti i druga obilježja proizvoda, poput imidža marke, imidža zemlje podrijetla, imidža prodajnoga mjesta, ambalaže i/ili temeljnih (unutrašnjih) obilježja proizvoda, a kako bi se utvrdilo koliko na percepciju kvalitete utječe cijena, a koliko prisutnost ostalih informacija o proizvodu. Zbog svega navedenog, rezultate provedenoga istraživanja trebalo bi smatrati indikativnima.

Unatoč navedenome, provedeno istraživanje ukazuje na potrebu razumijevanja važnosti koju potrošači pridaju cijeni u kupnji pojedinih kategorija proizvoda, kao i načina kako ju uopće percipiraju; primarno kao novčani trošak ili informaciju o kvaliteti proizvoda, a što se može smatrati bitnom odrednicom cjenovne strategije poduzeća. Budući da su potrošači koji su skloniji osloniti se na cijenu kao valjanog pokazatelja kvalitete manje cjenovno osjetljivi, i obrnuto, poznavajući da postoje razlike među potrošačima s obzirom na njihove moguće reakcije na cijenu u okviru pojedine kategorije proizvoda, marketinški stručnjaci mogu donijeti odgovarajuće odluke o odabiru ciljnog tržišnog segmenta, kao i o pozicioniranju svoje ponude odabranome segmentu potrošača, i to u okviru raspona cijena koje su tome segmentu prihvatljive. Nadalje, u komunikacijskome smislu, spoznaje o različitim razinama cjenovne osjetljivosti potrošača i njihovim različitim reakcijama na cijenu, mogu pomoći marketinškim stručnjacima u odluci što će se sadržajem oglašivačke poruke isticati; pristupačna cijena marke, kojom će se pojačavati cjenovna osjetljivost potrošača u odnosu na konkurentske proizvode, ili će se sadržajem poruke upućivati na jedinstvena 
svojstva proizvoda i time utjecati na smanjivanje cjenovne osjetljivosti ciljnog tržišnog segmenta u slučaju oglašavane marke.

\section{LITERATURA:}

1. Agarwal, S., Teas, R. K. (2001.): „Perceived Value: Mediating Role of Perceived Risk“, Journal of Marketing Theory and Practice, 9 (4), str. 1-14.

2. Anić, I.-D., Piri Rajh, S., Rajh, E. (2010.): „Razlike u stilovima odlučivanja potrošača s obzirom na spol ispitanika uz poseban osvrt na Hrvatsku“, Tržište, 22 (1), str. 29-42.

3. Aroean, L., Michaelidou, N. (2014.): ,Are innovative consumers emotional and prestigiously sensitive to price?“, Journal of Marketing Management, 30 (3-4), str. 245-267.

4. Bender, W. C. (1964.): „Consumer Purchase-Costs - Do Retailers Recognize Them?“, Journal of Retailing, 40 (1), str. 1-8, 52.

5. Bornemann, T., Homburg, C. (2011.): „Psychological Distance and the Dual Role of Price“, Journal of Consumer Research, 38 (3), str. 490-504.

6. Brucks, M., Zeithaml, V. A., Naylor, G. (2000.): „Price and Brand Name as Indicators of Quality Dimensions for Consumer Durables“, Journal of the Academy of Marketing Science, 28 (3), str. 359-374.

7. Cronin, Jr., J. J., Brady, M. K., Hult, G. T. M. (2000.): „Assessing the Effects of Quality, Value, and Customer Satisfaction on Consumer Behavioral Intentions in Service Environments“, Journal of Retailing, 76 (2), str. 193-218.

8. Dickson, P. R., Sawyer, A. G. (1990.): "The Price Knowledge and Search of Supermarket Shoppers", Journal of Marketing, 54 (3), str. 42-53.

9. Dodds, W. B. (1991.): „In Search of Value: How Price and Store Name Information Influence Buyer's Product Perceptions“, Journal of Consumer Marketing, 8 (2), str. $15-24$.

10. Dodds, W. B., Monroe, K. B., Grewal, D. (1991.): „Effects of Price, Brand, and Store Information on Buyers' Product Evaluation“, Journal of Marketing Research, 28 (3), str. 307-319.

11. Dominique-Ferreira, S., Vasconcelos, H., Proença, J. F. (2016.): „Determinants of customer price sensitivity: an empirical analysis“, Journal of Services Marketing, 30 (3), str. 327-340.

12. Duvvuri, S. D., Ansari, A., Gupta, S. (2007.): „Consumers' Price Sensitivities Across Complementary Categories“, Management Science, 53 (12), str. 1933-1945.

13. Erickson, G. M., Johansson, J. K. (1985.): „The Role of Price in Multi-Attribute Product Evaluations“, Journal of Consumer Research, 12 (2), str. 195-199.

14. Finlay, J. L., Hackmann, R., Schwarz, M. E. (1996.): "Price/Quality Associations within the Consumer Goods Market in the United Kingdom", Multinational Business Review, 4 (2), str. 71-78.

15. Goldsmith, R. E., Newell, S. J. (1997.): „Innovativeness and Price Sensitivity: Managerial, Theoretical and Methodological Issues", Journal of Product \& Brand Management, 6 (3), str. 163-174. 
16. Han, S., Gupta, S., Lehmann, D. R. (2001.): „Consumer Price Sensitivity and Price Thresholds“, Journal of Retailing, 77 (4), str. 435-456.

17. Imkamp, H. (2008.): „A New Look at Old Coefficients“, Journal of Consumer Policy, 31 (2), str. 139-145.

18. Kline, R. B. (1998.): Principles and Practice of Structural Equation Modeling, The Guilford Press, New York, NY.

19. Lichtenstein, D. R., Burton, S. (1989.): „The Relationship Between Perceived and Objective Price-Quality“, Journal of Marketing Research, 26 (4), str. 429-443.

20. Lichtenstein, D. R., Ridgway, N. M., Netemeyer, R. G. (1993.): „Price Perceptions and Consumer Shopping Behaviour: A Field Study“, Journal of Marketing Research, 30 (2), str. 234-245.

21. Moore, M., McGowan Kennedy, K., Fairhurst, A. (2003.): „Cross-cultural equivalence of price perceptions between US and Polish consumers“, International Journal of Retail \& Distribution Management, 31 (5), str. 268-279.

22. Nagle, T. T., Holden, R. K. (1995.): The Strategy and Tactics of Pricing: A Guide to Profitable Decision Making, Prentice Hall, Englewood Cliffs, NJ.

23. Nagle, T. T., Holden, R. K. (2002.): The Strategy and Tactics of Pricing: A Guide to Profitable Decision Making, Prentice Hall, Pearson Education, Upper Saddle River, NY.

24. Nelson, P. (1970.): „Information and Consumer Behavior“, Journal of Political Economy, 78 (2), str. 311-329.

25. Peterson, R. A., Merunka, D. R. (2014.): „Convenience samples of college students and research reproducibility“, Journal of Business Research, 67 (5), str. 1035-1041.

26. Rao, A. R., Monroe, K. B. (1988.): „The Moderating Effect of Prior Knowledge on Cue Utilization in Product Evaluations“, Journal of Consumer Research, 15 (2), str. 250-264.

27. Rao, A., Monroe, K. B. (1989.): „The Effect of Price, Brand Name, and Store Name on Buyers' Perceptions of Product Quality: An Integrative Review“, Journal of Marketing Research, 26 (3), str. 351-357.

28. Snoj, B., Pisnik Korda, A., Mumel, D. (2004.): „The relationships among perceived quality, perceived risk and perceived product value“, Journal of Product \& Brand Management, 13 (3), str. 156-167.

29. Sproles, G. B., Kendall, E. L. (1986.): „A methodology for profiling consumer decision-making styles“, The Journal of Consumer Affairs, 20 (2), str. 67-79.

30. Suri, R., Manchanda, R. V., Kohli, C. S. (2000.): „Brand Evaluations: A Comparison of Fixed Prices and Discounted Price Offers“, Journal of Product \& Brand Management, 9 (3), str. 193-206.

31. Taher, A., Basha, H. E. (2006.): „Heterogeneity of Consumer Demand: Opportunities for Pricing of Services“, Journal of Product \& Brand Management, 15 (5), str. 331340.

32. Tellis, G. J. (1988.): „The Price Elasticity of Selective Demand: A Meta-Analysis of Econometric Models of Sales“, Journal of Marketing Research, 25 (4), str. 331-341. 
33. Tellis, G. J., Gaeth, G. (1990.): „Best Value, Price-Seeking, and Price Aversion: The Impact of Information and Learning on Consumer Choices“, Journal of Marketing, 54 (2), str. 34-45.

34. Verma, D. P. S., Gupta, S. S. (2004.): „Does Higher Price Signal Better Quality?“, Journal for Decision Makers, 29 (2), str. 67-77.

35. Völckner, F. (2008.): „The Dual Role of Price: Decomposing Consumers' Reactions to Price“, Journal of the Academy of the Marketing Science, 36 (3), str. 359-377.

36. Völckner, F., Hofmann, J. (2007.): „The Price-Perceived Quality Relationship: A Meta-Analytic Review and Assessment of Its Determinants", Marketing Letters, 18 (3), str. 181-196.

37. Wakefield, K. L., Inman, J. (2003.): „Situational Price Sensitivity: The Role of Consumption Occasion, Social Context and Income“, Journal of Retailing, 79 (4), str. 199-212.

38. Yan, D., Sengupta, J. (2011.): „Effects of Construal Level on the Price-Quality Relationship“, Journal of Consumer Research, 38 (2), str. 376-389.

39. Zeithaml, V. A. (1988.): „Consumer Perceptions of Price, Quality, and Value: A Means-End Model and Synthesis of Evidence“, Journal of Marketing, 52 (3), str. 2-22.

\section{PRILOG}

Tablica 5. Varijable i sve pripadajuće tvrdnje korištene u istraživanju ${ }^{6}$

\begin{tabular}{|c|c|c|c|}
\hline Varijabla & & Tvrdnje & Izvor \\
\hline \multirow{4}{*}{$\begin{array}{l}\text { Odnos } \\
\text { cijene i } \\
\text { kvalitete }\end{array}$} & i_1 & $\begin{array}{l}\text { Općenito gledano, što je viša cijena (...), veća je } \\
\text { i njegova kvaliteta. }\end{array}$ & \multirow{4}{*}{$\begin{array}{c}\text { Lichtenstein, } \\
\text { Ridgway i } \\
\text { Netemeyer, } \\
\text { 1993., } \\
\text { prilagođeno }\end{array}$} \\
\hline & i_2 & $\begin{array}{l}\text { Izreka "što platiš - to i dobiješ", općenito je } \\
\text { točna kada je u pitanju (...). }\end{array}$ & \\
\hline & i_3 & Cijena (...) dobar je pokazatelj njegove kvalitete. & \\
\hline & i_4 & $\begin{array}{l}\text { Uvijek moraš platiti više kako bi dobio/la } \\
\text { najbolji (...). }\end{array}$ & \\
\hline \multirow{6}{*}{$\begin{array}{l}\text { Cjenovna } \\
\text { osjetljivost } \\
\text { potrošača }\end{array}$} & i_5 & Jeftiniji (...) bi uglavnom bio moj izbor. & \multirow{3}{*}{$\begin{array}{l}\text { Anić, Piri Rajh } \\
\text { i Rajh, } 2010 . \\
\text { (prema Sproles i } \\
\text { Kendall, 1986.), } \\
\text { prilagođeno }^{1}\end{array}$} \\
\hline & i_6 & $\begin{array}{l}\text { Prilikom kupnje (...) nastojao/la bih pronaći } \\
\text { najbolju vrijednost za svoj novac. }\end{array}$ & \\
\hline & i_7 & $\begin{array}{l}\text { (...) kupovao/la bih koliko je god to moguće po } \\
\text { sniženim cijenama na akcijama. }\end{array}$ & \\
\hline & i_8 & $\begin{array}{l}\text { Spreman/na sam uložiti dodatan trud kako bih } \\
\text { pronašao/la najnižu cijenu za (...). }\end{array}$ & \multirow{3}{*}{$\begin{array}{l}\text { Wakefield i } \\
\text { Inman, } 2003 .\end{array}$} \\
\hline & i_9 & Osjetljiv/a sam na razlike u cijenama (...). & \\
\hline & i_10 & $\begin{array}{l}\text { Promijenio/la bih planiranu odluku o kupovini } \\
\text { (...) ukoliko bih pronašao/la proizvod niže } \\
\text { cijene. }\end{array}$ & \\
\hline
\end{tabular}

Nakon utvrđivanja konvergentne i diskriminantne valjanosti, ove su tvrdnje izostavljene iz daljnje analize. 